\title{
Cooperation, Collaboration and Coordination: Education Librarians in Michigan \\ by
}

Katherine Corby, Shellie Jeffries and Darlene P. Nichols

\begin{abstract}
Formation of the Michigan Research Libraries Triangle consortium in 1991 served to bring the education librarians of Michigan State University, the University of Michigan and Wayne State University into a working relationship. The education programs at each institution have unique histories shaped by demographic, political and economic forces. The evolution of the programs profoundly influenced the physical and philosophical development of the education libraries at each institution and the education librarians have based their cooperation on the historic roles and unique strengths of each library's collection. The level of activity and opportunity for cooperation has fluctuated over the years due to institutional changes.
\end{abstract}

The education librarians of Michigan State University at East Lansing, University of Michigan at Ann Arbor, and Wayne State University in Detroit began meeting regularly in late 1994. Their initial meeting in Ann Arbor was an attempt to find ways for the three institutions to cooperate, particularly in the area of collection development. Cooperative collection proved an elusive goal, but the regular meetings and e-mail contact led to an intertwining of their professional lives. This paper looks at how their relationship has grown and continues to grow, while at the same time exploring the unique qualities of each institution's history that present challenges to their cooperative endeavors.

\section{Michigan Research Libraries Triangle (MRLT)}

Michigan Research Libraries Triangle was founded on May 31, 1991 by the libraries at Michigan State University, the University of Michigan, and Wayne State University. These three are the only members of Michigan's Association of Research Libraries (ARL). The goals of the initiative were to increase the resources available to residents of Michigan, particularly researchers at the institutions, by making the existing resources of each readily available to all, and by coordinating acquisitions to avoid unnecessary duplication. The goals, the technical language of the agreement, even the name of the consortium were adapted from the highly successful Triangle Research Libraries Network (TRLN) in North Carolina (Byrd, Davis, Gosling, \& Herman Jr., 1985).
MRLT began its work with four task forces to address the various issues the coalition wanted to engage: interlibrary loan (ILL), reciprocal borrowing, automation, and cooperative collection development. The Interlibrary Loan agreement, which already had received substantial work, was in place very quickly. It called for shortened response times, OCLC ILL, faxes for photocopies, and daily courier service for loaned material. Reciprocal borrowing privileges for faculty and graduate students went into effect in 1993. Both of these initiatives continue to the present.

The Automation Task Force directed its attention toward bringing in new money. In October of 1993, they obtained a Department of Education Title II-A grant for $\$ 300,000$ to initiate a project that allows each institution access to the others' online catalogs and links certain proprietary databases for use at all three. The grant also called for implementation of a patron-initiated ILL capability, but technical problems have prevented implementation.

The Assistant Directors for Collections from all three libraries began meeting almost immediately, looking for cooperative collection possibilities, areas where overlap could be avoided or in-depth collection of certain specific topics could be distributed among the three libraries. Over the course of the next four years they tried various approaches. They looked at subject funds appropriation levels, and current subscription lists. They did a survey of bibliographers to identify any existing formal or informal agreements. They even held a retreat. While education was 
mentioned in some of the early discussions, only French Studies, Agricultural Economics and U.S. History ever got to the point of having a draft written agreement. Progress may have been hindered by staff turnover. The chief collection officer at each school changed at least once, and in one case twice during the period. Each library system also had a change in dean/director during the period. Another problem was the extent to which the collections officers worked alone. They made attempts to involve selected librarians, but never approached faculty for support as Dominguez and Swindler (1993) indicate was vital to the success of similar efforts in North Carolina.

The MRLT education librarians also had difficulty finding common ground for cooperative collection work. Dane Ward, then Education Librarian at Wayne State, wanted to find a way to work together on textbooks or test materials. Neither of these were areas that all three institutions wished to pursue but the meeting did serve to give each one a better picture of the other's operations. As with other MRLT efforts, the new spirit of cooperation and coordination provided a tool for communication between colleagues.

Wayne State is an urban institution and its education program focuses on service to local schools resulting in a strong collection in urban education and multiculturalism. Michigan State started out as an agricultural institution and its first education efforts were directed toward farmers and rural life. It still maintains an excellent collection of agricultural education materials. The University of Michigan has always been strong in educational administration and research. There was a consensus that these varied strengths fit together well, but no formal agreement was written. Mr. Ward agreed to ask Wayne State to host a listserv for state education librarians that would allow the three librarians and colleagues throughout the area to exchange ideas.

The group met again in the summer of 1996. By that time there was less pressure from MRLT for selectors to find areas for collection cooperation. Furthermore, each librarian had taken on added responsibilities. All agreed that there was little time left for new projects. They looked for ways that they could do more with less. Ms. Corby, Michigan State's Education Librarian suggested that they create web pages that would have original content, such as brief reviews of smaller press and foreign education monographs, which might be of value to many selectors. Ms Corby and Ms. Nichols, the Education Librarian from the University of Michigan, agreed to work on the book review project, while Mr. Ward continued with the listserv. The web page entitled "Education Book Reviews" (http://www.lib.msu.edu/corby/reviews/index.htm) has attracted significant positive response, winning a "Top Site" award from Education Index, and being "adopted" as a monthly column by the electronic journal Education Review (http://www.ed.asu.edu ledrev/).
After considerable fluctuation in job assignments and personnel in the past eighteen months, all three MRLT institutions now have librarians assigned to education who do have time to focus on that effort. With this new sense of opportunity, the education librarians' group turned to the issue of cooperative collection once again. In Coordinating Cooperative Collection, Paul Mosher (1986) cites some statistics that seem almost impossible. A 1975 California study found $75 \%$ of Berkeley's holdings were unique in the north, and $45 \%$ of UCLA's in the south. Yet there was only 53\% overlap between Berkeley and UCLA. In New York, $87 \%$ of records at SUNY and Cornell are unique. Statistics from the Triangle Research Libraries of North Carolina are similar. Clearly cooperation can have a significant impact. Since building on historical strengths seemed like the most promising avenue to pursue, the three education librarians undertook a review of their institutional histories.

\section{Origins and Early Years Educating Educators in the Michigan Research Libraries Triangle}

Michigan State University, Wayne State University and the University of Michigan all offer teacher-training programs and provide library services in support of those programs. As public institutions subject to social and economic trends, they share some common patterns, but there are factors, which make each institution unique. The origin of each university's education program reflects the traditional strengths of the parent institution.

\section{Michigan State University}

Michigan State has a long tradition as an agricultural school and Beal (1915) notes that its College of Education grew out of an agricultural education program which began by teaching agricultural topics to farm families and rural high school students.

\section{Wayne State University}

Wayne State has strong ties to the City of Detroit. The Detroit Normal School was established in 1881 for the purpose of training female high school graduates to become teachers in the understaffed Detroitpublic school system. Between 1889 and 1920 the addition of new courses and teaching requirements, night classes, summer sessions, and male students, extended the twosemester program until, in 1920, Detroit Normal School became a four year institution and was renamed the Detroit Teachers College.

When graduate studies were offered for the first time in September 1930 , about $50 \%$ of the graduate students were in education, with a large percentage of them employed and studying part-time. The present university structure was formed, when the Detroit Board of Education, which governed five city colleges, decided to unite them into a university. At this time, the Teachers 
College became the College of Education. In 1934, the consolidated institutions became Wayne University. Doctoral programs were first offered in 1946.

Wayne State Library's education collection traces its roots to the Normal School. In 1930 the Normal School moved into the former Central High School Building (later known as Old Main) sharing the space with the College of the City of Detroit (CCD). A year later its "fairly adequate professional library" (Hanawalt, 1968) was integrated into the CCD library's holdings, bringing the collection of the College to 27,000 volumes. When Wayne University was established, this relatively small collection became its library. For many years, the Detroit Public Library newly built and only blocks away, supplemented the university collection.

\section{The University of Michigan}

At the University of Michigan teacher training has deep roots. In 1879, it became the first American college or university (outside of normal schools) to establish a permanent chair devoted exclusively to teacher preparation. In 1921, the Department of Education became the School of Education offering a Bachelor of Science. The School emphasized research in addition to teacher training in an effort to differentiate from the Normal School located only a few miles away in Ypsilanti. Other notable events in the School's early history included the opening of two demonstration schools, University High School in 1924 and University Elementary School in 1930. The School added a doctoral degree in 1938 .

Library materials in education were housed in the General Library, about a block away from the School of Education offices, but the School wanted an onsite collection. After several years of discussion and planning, a new branch library opened in January of 1941, on the fourth floor of the University High School. The School transferred its curriculum collection, textbooks, and pamphlets to the new facility. Use of the room was restricted, due at least in part to space constraints, remarked on even in the library's first year of operation (The University of Michigan, 1940-1941).

\section{The Boom Years for Education Schools: From Postwar through Baby Boomers}

Emphasis on teacher training increased greatly after World War II, when returning military personnel used government benefits to pursue higher education in record numbers. At the same time, the rising birth rate led to a rise in the number of teachers needed in the schools. The annual MSU Enrollment Report offers a graphic example of this boom. From 1947 to 1952, enrollment in the elementary education program at Michigan State remained steady at around 300 students. By the 1955-56 school year, the new College of Education boasted 1,868 undergraduate and 719 graduate students. The boom continued: 5,000 students in 1960; 6,500 in 1970 , when enrollments leveled of $f$ and began to decline. Wayne State's College of Education also experienced an influx of students after World War II, which, by 1948, increased the instructional load of the college by $50 \%$. From a low enrollment of 798 undergraduate students and 917 graduate students in 1942, numbers of matriculating students rose steadily to a high of 4,074 undergraduates and 3,957 graduate students in 1969. This pattern held true at the University of Michigan as well. Each institution responded to the pressure to accommodate this expansion in its own way.

\section{Michigan State University}

The College of Education at Michigan State, with its emphasis on K-12 teaching had an instructional materials center from the first days in its new building in 1957. As technology changed the classroom, the College of Education kept pace and instructional materials became essentially media equipment that could be plugged in. Print materials were an afterthought, as professors donated materials from their own collections of K-12 texts and children's literature.

Michigan State opened its new main library building in 1956, the same year that the School of Education became the College of Education. Towne (1961) notes that the new library was organized into subject divisions, and an Education Division was present from the start. These divisional units operated like separate libraries, with separate staff, budgets, reference services, and reserve reading. They relied on centralized circulation, acquisitions and cataloging. This model was progressively less satisfactory as enrollment continued torise. In 1965, reorganization merged library resources with a newly erected graduate research library adjacent to the existing facility, which became an undergraduate library. The 1964 -65 year was the last for operation of the Education Division, which became part of the newly centralized services. Michigan State University responded to the problems created by increased enrollments by consolidating facilities and services.

\section{Wayne State University}

Over the years, the College of Education at Wayne State maintained a close working relationship with the Detroit Public School system, whose board governed the University. It was not until 1956 that Wayne became a State University managed by a Board of Governors. The relationship between the Board of Education and Wayne University was unique in the nation and defines, even today, the relationship between Wayne State and its students. Wayne State identifies itself as an urban institution and works to accommodate the needs of its urban students, $88 \%$ of who are drawn from the tri-county area of Wayne, Oakland and Macomb counties.

As Wayne University grew, so did its libraries. The space for the combined collection of the College of the City of Detroit and the Teachers College was "unable to contain the growing college collection" (Engle \& Borgman, 1984, p.21). The university library had created an "Education Laboratory Collection," most likely 
founded on the original Teachers College core collection. In 1949, that collection was physically separated from the university library's holdings and moved to space on the fourth floor of Old Main, a former high school lunch room. In this way the first incarnation of the Wayne State University Education Library as a physically separate collection came to be.

After thirteen years of planning, Library Director G. Flint Purdy obtained funding to build a new library and, in 1950 construction began on a general library and a science library, two separate but adjoining buildings. The new General Library opened its doors in 1953, with the Education Library filling the fourth floor of the new building and employing a head librarian, 4 1/2 reference librarians and an average of eight part time students. Other floors in the building supported the Humanities and Social Science divisions of the library; each division had its own staff, and its own reference and circulation desks. In 1970 the Education Library moved into the Kresge building when the science library moved out. Wayne State University accommodated the expanded enrollment and increased demands on its facilities and services by organizing and expanding into separate facilities and maintaining branch libraries.

\section{The University of Michigan}

The postwar period also saw rapid expansion at the University of Michigan School of Education. Many new programs were added, such as higher education, and guidance and counseling. Enrollment skyrocketed. The school's graduate program enrolled a significant percentage of the university's graduate students: $25 \%$ during the regular school year and close to $50 \%$ in the summer sessions (Williams, 1997, p.32). The school was stretched to its limit and halted the growth of enrollment in the early 1960's.

The Education Library existed as a separate facility during the boom years. The library collection grew steadily — with many faculty donations - and won occasional laudatory mention in the school's annual report. In 1950, for example, particular notice was made of the library's text and thesis collections. Demands on the physical facility, however, could not meet the growing school's needs. The seating capacity was 58 (University of Michigan Library, 1953), hardly adequate for a student body of over a thousand. It was the space issue that led the library to move this branch into the Undergraduate Library building when it opened in January 1958. Even that new space rapidly became too small. By 1964 arrangements were made for readers to use adjoining space in the Undergraduate Library. Although now in a separate building from the library, the School of Education continued to keep a hand in planning. In 1964, the School established a faculty Library and Instructional Materials Committee charged "to develop further the use of the existing library" (The President's Report, The University of Michigan, 1964-1965, p. 48). Like the library, the committee, too, remarked on the need for more money and more space (The University of Michigan, 1965-1966, p. 42).

\section{The 1970's and beyond}

In the early 1970's, a statewide economic crisis created a significant impact on public universities. At the same time the demand for teachers, which had fueled the rapid expansion of the schools of education, began to decline. Retrenchment and reorganization were constant over the next few years.

\section{Michigan State University}

Through the 1970's, enrollment in Michigan State's College of Education dropped from its 1970 peak of 6,500. By 1985 it had reached 2,000-2,500 students, about equally divided between undergraduate and graduate programs, where it remains.

In the late 70's, the college received a major federal grant to set up the Institute for Research on Teaching. It turned to the main library for help in hiring a librarian to work with that project and help with the acquisition of print materials for the media center. When the center outgrew its home, print materials were left in the original location and media were moved to another floor. This left a librarian and library clerk in charge of the collection of texts and children's literature. In the early 90 's, this teaching resources library was eliminated and its collections dispersed.

In the 70's, the main library experienced a complex of financial problems. Major serial deselecting projects were carried out, but there were years when there was no money at all for monographs. Staffing for the research library was also a problem. The bibliography unit had only three librarians, each of whom had to cover large subject areas. Many collection maintenance functions were being neglected. As the seventies drew to a close the library again instituted a major reorganization, eliminating the separate research and undergraduate libraries and unif ying services at the main library.

The eighties saw a gradual growth in the numbers of librarians given collection development duties. 1986/87 was the first year that a few librarians were officially listed as holding dual positions as both public services librarians and bibliographers for a given discipline (Annual Report, 1986-87). This model, currently the norm at Michigan State, was followed when a new bibliographer /reference librarian was appointed in 1991 to serve the College of Education.

During the nineties the computer has become a focal point for change in most libraries. Michigan State's Education librarian and College of Education now work together on a variety of electronic related projects. Software for classrooms, particularly at the kindergarten to grade 12 level has been one ongoing concern. The software needs to be accessible for faculty uses in the classroom and for students who need to familiarize themselves with it both from a mechanical and a pedagogical standpoint. The usual access problems are compounded by the of ten-restrictive licensing agreements of the producers. In the last few years the 
College of Education has offered an increasing number of distance and web based courses. Service to these students is an evolving scenario that changes as quickly as what can be posted on the web and how sophisticated a computer set-up the library feels it can require. The Education librarian is called upon to be involved in copyright permission issues and web page design consultations that were unheard of only a few years ago.

\section{Wayne State University}

In 1971, Wayne State's College of Education undergraduate enrollment began to fall drastically, continuing to a low of 515 students in 1985. The drop in graduate enrollment was not nearly as precipitous; 2,035 graduate students were enrolled in 1985. Even today, with recent figures placing Wayne State's College of Education enrollment at $28 \%$ of the total of graduate students, the College has the largest proportion of the student body of any college at Wayne State. And, as was the case in the 1930s, a vast number of these graduate students are employed and studying part time.

Decline in the enrollment of Wayne State's College of Education was paralleled by a similar decline across the university. Because of this, the library system suffered a budgetary crisis that led to the unification of the separate divisional libraries housed in the Purdy and Kresge buildings. In 1985, the Education Library collection was integrated into the Purdy Library collection of Humanities and Social Science materials. The Education Library as a separate entity ceased to exist. The former education librarians were assigned other duties, with one being designated as the education librarian.

At this time, one librarian is assigned liaison duties to the College of Education. She is currently focusing on collaboration, investigating the ways in which she and the College of Education faculty can work together more closely and cooperatively to enhance library services to both faculty and students. In the near future she will need to introduce Education faculty and students to the library's new Horizon online catalog, and teach them how to utilize the variety of education related databases to which the library will be subscribing. Additionally, she will be closely involved with creating web-based pathfinders in the field of education as the WSU Library System increasingly incorporates web sites into its online catalog.

\section{The University of Michigan}

In 1969 an external review described the University of Michigan School of Education as fragmented and lacking welldefined goals. Streamlining was critical and within a year the University of Michigan followed other state universities by closing its lab schools. Many programs were eliminated or consolidated. The School of Education took over the entire building that had housed the lab schools and began retooling. Streamlining did not preclude the addition of new programs and, following emerging social trends, the school began to develop activities related to urban education, school desegregation programs, and minority recruitment.

The School of Education was not the only unit to suffer cutbacks during this period. Campus-wide, units tightened their belts, cutting services and programs. Driven by financial constraints the Dean of the School of Education and the Director of the University Library agreed to close the Education Library in 1973. Collections and services supporting education were dispersed into the Undergraduate and the Graduate Libraries. Each library was expected to maintain and develop those areas as part of its regular, ongoing responsibilities. The education librarian was appointed to a position in the School of Education and his reference and collection management responsibilities were assigned to librarians already in the Undergraduate and Graduate Libraries.

A new crisis struck the School in 1982. The University was facing a $\$ 12$ million budget shortfall and the School of Education became one of three units under consideration for major reductions or elimination. Ultimately the school took a $40 \%$ budget reduction over five years. In the years since, the school has restored some losses. It has remained strong in research and continued to develop innovative programs, particularly in the use of technology.

Library services in education have changed over the two decades since the branch library was closed. The split responsibilities led to collection overlaps in some areas and gaps in others. Split collections left users uncertain of where to go for the bulk of materials relevant to their research. In partial remedy of this confusion, the Graduate Library agreed in the 1990's to become the primary location for all research-level materials in all areas of education. The Undergraduate Library agreed to retain the materials already in house and to continue collecting materials appropriate to undergraduate education. The two libraries continue to work together to refine collections and services to the School of Education.

Currently at the University of Michigan, the librarian is seeking to forge closer ties to the School of Education, meeting with staff from the school's information technology unit to discuss cooperative efforts, including the possibility of developing new digital resources.

\section{Looking to the Future}

An important development for cooperation in Michigan was the appointment of George Needham as State Librarian in 1996. His priority is to bring a statewide information system to Michigan. Among the components of his plan, called AccessMichigan, various state library organizations cooperate to provide the Michigan Electronic Library of freely accessible web sites, OCLC interlibrary loan, state-wide 24 hour courier service, and access to proprietary 
databases through FirstSearch and UMI. The statewide model of equal access for all will necessitate a broader scope for grantwriting and cooperative projects than MRLT or its three education librarians had originally envisioned.

Gathering this history has clarified each institution's unique mission. The lessons learned both from the history and the review of the literature of other cooperative efforts have forced a focus on certain realities. The historic strengths of our collections will continue without formal agreement. Presently, serials and electronic access are more appropriate points of attention than monographs. For education related subjects, current MRLT plans include coordination of journal and microf orm selections to broaden access or avoid duplication. There has been some discussion of sharing access to little used and expensive reference resources, which in the case of print materials, would involve a change in current interlibrary loan policy.

Deselection is another area where the librarians' shared historic knowledge will assure that one institution is not disposing of resources that would be valuable to a sister institution. Beyond this, for now at least, the future appears to be on the web. The book review page continues. Institutional efforts will increasingly make unique historic collections available in full on the web, many of which will be significant for educational researchers. For example, Michigan State has just received $\$ 200,000$ in funding from the National Endowment for the Humanities for an "Historical Voices" project which includes funds to digitize many of the resources of the Vincent Voice Library. This will make the voices of historic world figures freely available on the web for use by educators at all levels. These types of projects generate excitement and truly allow us to teach in ways that would not have been previously possible. They also confirm the importance of coordinated effort and explicit priority setting to assure that existing strengths and traditional functions continue to be part of our service equation. The institutional histories we have shared, and the professional relationship we've built will assure that our efforts will continue to be coordinated at an important, if informal, level.

\section{REFERENCES}

Annual Report. (1986/87). East Lansing, MI: Michigan State University Libraries. Beal, W. J. (1915). History of the Michigan Agricultural College and Biographical Sketches of the Trustees and Professors. East Lansing, MI: The College.

Byrd, G. D., Davis, J. Y., Gosling, W. A., \& Herman Jr., L. R. (1985). The Evolution of a Cooperative Online Network; Lessons from the History of the Triangle Research Libraries Network. Library Journal, 110, 71-77.

Dominguez, Patricia Buck, \& Swindler, Luke (1993) Cooperative Collection Development in the Research Triangle University Libraries: a Model for the Nation. College and Research Libraries, 54, 470-496.

Engle, Constance B., and Borgman, Betty C. (1984) Profile of the Kresge (Education) Library. Education Libraries, 9, (Fall) 21-24.

Hanawalt, L. L. (1968). A Place of Light: the History of Wayne State University. Detroit: Wayne State University Press.

Michigan State University. Office of the Registrar (1954-1995). Enrollment Report. East Lansing, MI: The University.

Mosher, Paul H. (1986) A National Scheme for Collaboration in Collection Development: the RLG-NCIP Effort. In Wilson Luquire (Ed.), Coordinating Cooperative Collection Development: a National Perspective (pp.21-35). New York: Haworth Press.

Towne, Jackson E., (1961) A History of the Michigan State University Library, 1855-1959. Rochester, NY: University of Rochester Press for the Association of College and Research Libraries. 
The University of Michigan. (1940-1941). The President's Report Ann Arbor, MI: The University of Michigan.

The University of Michigan. (1964-1965). The President's Report. Ann Arbor, MI: The University of Michigan.

The University of Michigan. (1965-1966). The President's Report. Ann Arbor, MI: The University of Michigan.

University of Michigan Library. (1953). The Library Situation and the Program of Plant Extension. Unpublished Report to the Library Committee of the College of Literature, Science and the Arts.

Williams, B. A. (1997). The Science and the Art of Teaching: the 75th Year of the University of Michigan School of Education. Ann Arbor, MI: The School of Education.

Katherine Corby is Education and Psychology Bibliographer and Reference Librarian at Michigan State University, East Lansing, MI, USA. E-mail: corby@pilot.msu.edu

Shellie Jeffries is the Education and Anthropology Librarian at Wayne State University in Detroit, MI, USA. E-mail: ac0656@wayne.edu

Darlene P. Nichols is Education and Psychology Librarian at the Graduate Library, The University of Michigan, Ann Arbor, MI, USA. E-mail: dpn @umich.edu 